\title{
Extent and Severity of Caries Among 12 year-old Students in an Endemic Fluorosis Area in Senegal
}

\author{
Daouda Cisse ${ }^{1}$, Massamba Diouf ${ }^{1}$, Cheikh M. Mbacké Lo ${ }^{1}$, Marthe Diouf ${ }^{2}$, Daouda Faye ${ }^{1}$ \\ ${ }^{1}$ Public Health Service, Department of Dentistry, University Cheikh Anta Diop, Dakar, Senegal \\ ${ }^{2}$ Free-lancer, Kaolack, Senegal
}

Email address:

daoudacisse@hotmail.com (D. Cisse)

To cite this article:

Daouda Cisse, Massamba Diouf, Cheikh M. Mbacké Lo, Marthe Diouf, Daouda Faye. Extent and Severity of Caries Among 12 year-old Students in an Endemic Fluorosis Area in Senegal. Science Journal of Public Health. Vol. 3, No. 6, 2015, pp. 883-887. doi: $10.11648 /$ j.sjph.20150306.24

\begin{abstract}
The aim of this study was to measure the extent and severity of caries among 12 year-old students in an endemic fluorosis area of Senegal. This was a descriptive and cross sectional study covering 253 elementary school students aged 12 years and attending public, confessional and Franco-Arab schools in the city of Kaolack (Senegal). These students were in grades 4 or 5 and obtained parental permission to participate in the survey. They were selected through a cluster sampling; twenty two clusters were drawn at random. The socio-demographic information, the caries prevalence, the DMFteeth (DMFt) index and the degree of fluorosis were collected. The data was analysed using Epi info with a significance level of 5\%. Girls constituted $54.2 \%$ of the sample; students in public schools were $46.8 \%$ and those in confessional schools were $31.23 \%$. The prevalence of dental caries was $28.1 \%$; the DMFt mean was 0.52 (sd 0.41 ), while $90.5 \%$ of the school population were affected by fluorosis. The prevalence of caries was significantly higher in the Franco-Arab schools than in confessional and public schools with a p-value $=0.0105$. The caries prevalence and the mean DMFt remain relatively low in an area where $9 / 10$ of the school population were affected by fluorosis. Prevention programs based on inequalities related to the types of schools are an efficient strategy to fight dental caries in the city of Kaolack.
\end{abstract}

Keywords: Dental Caries, Dental Fluorosis, 12 Year-Old Student, Senegal

\section{Introduction}

Dental caries is a demineralisation of the hard tissue of the tooth. It is caused by an acid attack coming from the bacterial metabolism. The host (tooth), the bacterial plaque, food intake and time are the main contributing factors to its occurrence. It affects all layers of the population, particularly children. Sixty-ninety percent of the school populations suffer from it. [1] The prevalence of caries is generally higher in developing countries. In schools, it is $77.7 \%$ in India [2], $61.9 \%$ in Libya [3], 77.2\% in the North West of Ivory Coast [4] and 52.1\% in Senegal [5]. As for the dental fluorosis condition associated with an excess of fluorine, it is characteriszed by the presence of chalky spots frosted white on the surface of the tooth. In contrast, a fluorine concentration of about $1.5 \mathrm{mg} /$ day provides for children a resistance to the enamel against caries. Indeed a significant reduction in the severity of caries was associated with the introduction of fluorine-based prevention program in some countries. In Slovenia a decrease in the DMFt from 5.1 to 1.8 in the 12-year period was noticed among 12 year- old students [6]. Also, in France and Greece a reduction of DMFt was observed after evaluation of prevention programs [7, 8]. In Senegal, however, prevention programs are almost nonexistent. Epidemiological studies among 12 year-old students in Central West Senegal are very rare. The objective of this study was to measure the extent and severity of caries among 12 year-old students in an endemic fluorosis area (city of Kaolack) of Senegal.

\section{Methodology}

\subsection{Type Setting and Studied Population}

This was a descriptive and cross-sectional study that was conducted in elementary schools, in the city of Kaolack situated in the Central West of Senegal. This city represents the heart of the groundnut fields [9]. It has 46 public schools, 9 private confessional schools and 13 private Franco-Arab 
schools. The study population consisted of 12 year-old students attending elementary schools in Kaolack.

\subsection{Selection Criteria}

Any student aged 12 years [10], in grades 4 or 5 in elementary school and whose parents had authorized the participation in the survey, was part of the study. However those who were absent on the day of the survey, due to illness or for any other reasons, or whose actual age did not correspond to the reported age of birth, were not considered. Those who refused to participate in the survey despite their parents' agreement were also not included in the survey.

\subsection{Sampling and Sample Size}

Three strata were defined: public schools, confessional schools and Franco-Arab schools. In each stratum a cluster sampling was conducted. Each elementary school represented a cluster. All clusters that had no $4^{\text {th }}$ or $5^{\text {th }}$ grades were excluded from the outset. The number of clusters required in each stratum was determined according to a table prepared by Lutz, which fixes the sample size for a cluster survey based on proportion like preliminary estimates [11]. The estimated proportion was $48.66 \%$, corresponding to the prevalence of caries in the town of Gandiaye [12] near the city of Kaolack. A simple random sampling was made to select clusters. The clusters drawn were 10 clusters for public schools out of a total of 42 clusters; 6 clusters for Franco-Arab schools out of a total of 9 clusters; 6 out of 6 clusters for the confessional private schools. All statistical units in selected clusters, which fulfilled the selection criteria, were interviewed. A maximum size of 120 was expected for each of the three strata. Finally, a size of 117 was obtained for public schools, 79 for confessional private schools and 57 for Franco-Arab schools for a total of 253. The desired size has not been reached because many students were younger than the actual age. However all students meeting the selection criteria were selected.

\subsection{Studied Variables and Indicators}

\subsubsection{Socio-Demographic Variables}

Socio-demographic variables were based on gender, type of school and parents' occupations.

\subsubsection{Indicators}

Indicators related to dental state were based on prevalence, DMFt and Dean's fluorosis indices [10].

i. The prevalence of dental caries is the ratio between the total number of students with at least one cavity and the total number of examined students. It reflects the extent to which tooth decay exists. Any tooth that had a cavity related to caries, or a temporary filling or a recurrence of decay in a permanent filling was considered decayed.

ii. The DMFt index characterising the severity of the carious lesion shows the number of permanent decayed (D), missing (M) and filled (F) teeth among the studied population. Component D corresponds to all decayed teeth, component $\mathrm{M}$ corresponds to all missing teeth and component $\mathrm{F}$ corresponds to all teeth with permanent filling of cavities without recurrence.

iii. Dental fluorosis was evaluated using the Dean index that determines the degree of fluorosis in the teeth. This index is coded 0 to 5 :

$0=$ Normal: the surface of the enamel is smooth, glittering and in an ordinary light white cream, there is no dental fluorosis;

1=Doubtful: the normal enamel translucency shows light alterations going from white light speckles to scattered spots;

$2=$ Very light: small opacities are white and irregular, spread on the tooth, but do not touch more than $25 \%$ of the vestibular surface;

3 =Light: the white opacity of the enamel is wider than it is for Code 2, but covers less than $50 \%$ of the tooth.

4=Moderate: the enamel of the tooth shows a significant wearing down and its colour is often altered by brown stains;

5=Serious: the enamel is seriously attacked and the hypoplasia is so advanced that the general form may be impacted. Dotted and worn out zones can be observed with numerous brown stains; teeth often have a corroded look.

\subsection{Data Collection}

Data was collected using a data collection form that was corrected after a pre-test done in Kaolack among students aged 12 attending college. After authorisation of education authorities, a parental consent form was distributed to students aged 12. Another passage allowed to administering the questionnaire to children whose parents had signed the consent. No child was forced to participate in the survey which took place from Monday to Friday, morning and afternoon following schedules set by teachers. Identified students responded to the questionnaire and were then examined in daylight using the review board. The survey was conducted from June 8 to June22, 2009.

\subsection{Data Analysis}

The software Epi Info 3.4.3 was the tool used to make data entry and data processing. The modalities of some variables were grouped in statistical calculations for an epidemiological interest, including the fluorosis codes 2, 3, 3 and 5, which were gathered into a single modality, "yes." The results of univariate analysis were expressed in frequency and mean with standard deviation. The comparison in bivariate analysis was made by the Chi2 test for the proportions. The tests were significant when the $\mathrm{p}$ value was less than 0.05 .

\section{Results}

In this sample 54.2\% were girls; public school students were $46.25 \%$ and confessional school students were $31.23 \%$. The sex ratio was equal to $116 / 137=0.85$. 
Table 1. Socio-demographic characteristics of the sample.

\begin{tabular}{llll}
\hline Variables & Modalities & Frequency & $\begin{array}{l}\text { Relative } \\
\text { Frequency (\%) }\end{array}$ \\
\hline \multirow{2}{*}{ Sex } & Male & 116 & 45.8 \\
& Female & 137 & 54.2 \\
Type of & Public & 117 & 46.25 \\
School & Confessional & 79 & 31.23 \\
& Franco-arab & 57 & 22.52 \\
Parents' & Civil servants & 56 & $22.1 \%$ \\
occupations & Trader or labourer & 160 & $63.3 \%$ \\
& Company worker & 37 & $14.6 \%$ \\
\hline
\end{tabular}

Dental caries prevalence was $28.1 \%$ while fluorosis prevalence was $90.5 \%$.

The prevalence of caries was significantly higher in
Franco-Arab schools (43.9\%) than in confessional schools $(24.1 \%)$ and public schools $(23.1 \%)(p=0.0105$; Chi $2=$ 9.116). The prevalence of dental fluorosis was not significantly associated with the type of school $(\mathrm{p}=0.122$, Chi $2=7.272$ ).

Table 2. Prevalence of dental caries and fluorosis among students.

\begin{tabular}{llll}
\hline Indicators & Modalities & Frenquency & $\begin{array}{l}\text { Relative } \\
\text { Frequency (\%) }\end{array}$ \\
\hline \multirow{2}{*}{ Caries prevalence } & Yes & 71 & 28.1 \\
& No & 182 & 71.9 \\
\multirow{2}{*}{ Fluorosis prevalence } & Yes & 229 & 90.5 \\
& No & 24 & 9.5 \\
\hline
\end{tabular}

Table 3. Association between caries prevalence, dental fluorosis prevalence and school type.

\begin{tabular}{|c|c|c|c|c|c|c|c|c|}
\hline \multirow{2}{*}{ Variables } & \multirow{2}{*}{ Moda-lities } & \multicolumn{6}{|c|}{ School } & \multirow{2}{*}{ p_value } \\
\hline & & \multicolumn{2}{|c|}{ Public n\% } & \multicolumn{2}{|c|}{ Confessional n\% } & \multicolumn{2}{|c|}{ Franco-arab n\% } & \\
\hline \multirow{2}{*}{ Caries prevalence } & Yes & 27 & 23.1 & 19 & 24.1 & 25 & 43.9 & \multirow{2}{*}{0.0105} \\
\hline & No & 90 & 76.9 & 60 & 75.9 & 32 & 56.1 & \\
\hline \multirow{2}{*}{ Fluorosis prevalence } & Yes & 107 & 91.4 & 74 & 93.7 & 48 & 84.2 & \multirow{2}{*}{0.122} \\
\hline & No & 10 & 8.5 & 5 & 6.3 & 9 & 15.8 & \\
\hline
\end{tabular}

Table 4. Distribution of DMF teeth based on school type.

\begin{tabular}{|c|c|c|c|c|c|c|c|}
\hline \multirow{3}{*}{$\begin{array}{l}\text { DMFt } \\
0\end{array}$} & \multicolumn{6}{|c|}{ School } & \multirow{3}{*}{ p_value } \\
\hline & \multicolumn{2}{|c|}{ Public n\% } & \multicolumn{2}{|c|}{$\begin{array}{l}\text { Confessional } \\
\mathrm{n} \%\end{array}$} & \multicolumn{2}{|c|}{$\begin{array}{l}\text { Franco-arab } \\
\text { n\% }\end{array}$} & \\
\hline & 90 & 76.9 & 60 & 75.9 & 32 & 56.1 & \\
\hline 1 & 13 & 11.1 & 13 & 16.5 & 14 & 24.6 & \multirow{3}{*}{0.0140} \\
\hline 2 and plus & 14 & 12.0 & 6 & 7.6 & 11 & 19.3 & \\
\hline Total & 117 & 100 & 79 & 100 & 57 & 100 & \\
\hline
\end{tabular}

The severity of dental caries was almost twice as great in Franco-Arab schools as in public schools $(\mathrm{DMFt}=1 ; 24.6 \%$ vs. $11.1 \%)(\mathrm{DMFt}=2$ and plus; $19.3 \%$ Vs. $12.0 \%)(\mathrm{p}=$ 0.014 , Chi $2=12.499$ ). The mean DMFt was $0.52 \pm 0.41$; with $98 \%$ of decayed teeth $0.8 \%$ of missing teeth and $0.4 \%$ of filled teeth.

\section{Discussion}

\subsection{Methodological Limitations and Considerations}

The sample size was 253 students against 360 students that were expected. This decrease is due to the insufficient number of students aged 12 actually. Added to this, is the proportion of students who refused to participate in the study (2\%). This insufficiency of the sample size can affect the accuracy of the results. However all the students who met the selection criteria in the clusters were selected. Moreover, the random selection of clusters allowed the minimisation of selection bias. To limit the information bias, the administration of the questionnaire was carried out by a single person for all the students in all schools. These steps (cluster selection and questionnaire administration) must have contributed to the improvement of the validity of the results.

\subsection{Socio-Demographic Data}

There were more girls (137) than boys (116) (Table 1). This corresponded to a sex ratio of 0.85 . This repartition ratio reflects that of the Kaolack regional population with a sex ratio of 0.94 , and also that of the departmental (sex ratio 0.94 ) and communal populations (sex ratio 0.90). There are more girls going to school (52\% at regional level) than boys because of awareness campaigns that aim at encouraging parents to send their daughters to school [9]. These results confirm our opinion in the minimisation of the selection bias. The largest number of 12 year-old students came first from public schools then from confessional schools. This could be related to the greater number of public schools. Indeed, the public school students accounted for $94.48 \%$ of primary school students in the region of Kaolack [9]. Public school is generally more financially accessible. The low attendance of Franco-Arab schools would be linked to the recent advent of this type of school, the good organisation of which some parents might doubt. In this study, over half of the students' fathers were traders or labourers (63.3\%) (Table1). These occupations were considered low socioeconomic statuses justified by a lack of enterprises in a city where the main activity is agriculture [9].

\subsection{Extent of Tooth Decay}

The prevalence of caries found in this study was $28.1 \%$ (Table 2). This prevalence was low compared to that found by Lo et al. [13] in the region of Dakar (82\%) and that found by Mbengue [14] in the region of Thies (34.1\%). This disparity could be explained by the presence of fluoride in the waters of Kaolack city. Indeed, when fluorides stick to the enamel, they replace hydroxyl groupings and produce fluorapatite which is more resistant to dissolution by acid 
than hydroxyapatite and this, in some way, prevents dental caries. A study among 12 year- old students in France showed a prevalence of $34.6 \%$ [15]; the results of two national studies done among 12 year-old children in Germany in 2004 and 2009 showed prevalence rates of $39.3 \%$ and $31.0 \%$ respectively $[16 ; 17]$. Another study in Lithuania in the same age group showed a prevalence of $85.5 \%$ [18]. Referring to WHO, prevalence higher than $80 \%$ is moderate to high [10]. The high prevalence would be associated with eating habits of school children who consume more sweets without adequate oral hygiene measures. The prevalence of dental caries was significantly higher in Franco-Arab schools (43.9\%) than in confessional and public schools $(p=0.0105)$ (Table 3$)$. This is due, in part, to the integration of oral hygiene teaching in public and confessional schools programs [19]. All the students in the 3 types of schools were not differently affected by fluorosis $(\mathrm{p}=0.122)$. More than $9 / 10$ th of the students $(90.5 \%)$ had fluorosis (Table 3$)$. Fall had found that $84.6 \%$ of students had fluorosis in Diourbel [20] and Cisse had found $66 \%$ in Fatick. [21] These high rates could, in the future, decrease due to defluoridation policies [22].

\subsection{Severity of Dental Caries}

The mean DMF index was equal to $0.52 \pm 0.41$. It is considered very low according to $\mathrm{WHO}$, as it is in the range 0.0 to 1.1 [18]. It is comparable to 0.72 of mean DMF found in a national survey in Germany on the same target [16]. It consisted of more than $98 \%$ of decayed teeth and only $0.4 \%$ of filled teeth, reflecting low visits to dental practices by students. These results suggest that the use of modern treatments is not systematic during dental pain in an environment where the practice of traditional medicine and self-medication are not absent [23]. DMFt index was higher in Franco-Arab schools where students were almost twice as severely affected as those in public schools (Table 4). Doumit and Doughan had found in Lebanon [24] in 2002 that 12 year-old students who attended private schools were more severely affected than those studying in public schools. The Okeigbemen's paper [25] in Nigeria also showed a higher DMT index in private and public schools. The interpretation that can be made of these results may be economical or cultural: students who attended private schools were generally from rich families who tended to receive from their parents enough money to buy cariogenic foods and snacks; children who studied in public schools had cheaper meals generally low in fermentable sugar; the gap between the severity of caries between Franco-Arab school students, on the one hand, and confessional religious and public school students, can be explained by cultural reasons; indeed, Diouf et al in Senegal showed that $81 \%$ of children (mean age $9.3 \pm$ 0.4 ) attending Koranic schools (comparable to Franco-Arab schools) did not use a toothbrush or rub teeth stick [26]; So the assumption that Franco-Arab school students are more severely affected by tooth decay because they are less sensitised to oral hygiene measures than confessional and public school students seems plausible.

\section{Conclusion}

The prevalence of dental caries and the DMF index remain low among 12 year- old students in Kaolack city. Although these indicators are comparable to those found in Western Europe (France, Germany), the factors involved do not seem to be the same. Indeed, the presence of fluoride in the drinking water (endemic fluorosis area) certainly contributed to the reduction of the prevalence and the DMF indices that are significantly different in public, confessional or Franco-Arab schools. Because students are equally affected by dental fluorosis, the differences are probably in oral health that stem from economic, social and cultural inequalities that authorities must face through community programs of prevention and promotion of oral health.

\section{References}

[1] WHO. Oral Health. Fact Sheet 2007; 318.

[2] Grewal H, Verma M, Kumar A. Prevalence of dental caries and treatment needs in the rural child population of Nainital District, Uttaranchal. J Indian Soc Pedod Prev Dent. 2009; 27: 224-226.

[3] Al-Sharbati MM, Meidan TM, Sudani O. Oral health practices and dental caries among Libyan pupils, Benghazi (1993-94). East Mediterr Health J. 2000; 6: 997- 1004

[4] Yao KJ, N'da NA, Koffi NM. Prevalence of dental caries in schools in the north west of Ivory Coast. Med. trop. 2001; 61: 148-152.

[5] Sembene M, Kane AW, Bourgeois D. Caries prevalence in 12 years-old schoolchildren in 1989 and 1994. Int Dent $J$ 1999; 49: $73-75$

[6] Vrbic, $V$. Reasons for the caries decline in Slovenia. Community Dent Oral Epidemiol. 2000; 28: 126-132.

[7] Dargent-Pare C, $W M$, Brafman J, Letrait S, Boissonnat V, Espie J. Prevalence of dental caries in children before and after a prevention program in Seine-Saint-Denis. Rev d'épidémiol santé publique. 1999; 47: 19-28.

[8] Demertzi A, Topitsoglou V, Muronidis S. Caries prevalence of 11.5 year-olds between 1989 and 2001 in a province of NorthEastern Greece. Community Dent Health. 2006; 23: 140-146.

[9] National Agency of Statistics and Demography. Economic and social situation of the Kaolack region in 2008. www.ansd.sn/publications/annuelles/SES_Region/SES_Kaola ck_2008.pdf.

[10] WHO. Oral health survey: basic methods. 2013. [Internet]. [Cited 05/11/ 2014]. Available: http://www.icd.org/content/publications/WHO-Oral-HealthSurveys-Basic-Methods-5th-Edition-2013.pdf.

[11] Lutz W. Surveys of community health: how to form samples of individuals, households, zones, for the study of the community's health problems. National School of Public Health. Rennes, France, 1986. 
[12] Ndiaye KR. Study of endemic fluorosis and its impact on the oral health of children. Survey conducted in schools in the municipality of Gandiaye. Thèse: chir. Dent. Dakar 2004.

[13] Lo CM, Faye D, Gaye F, Cisse D, Yam AA. Tooth decay study in public primary schools under the Health Centre Nabil Choucair Dakar Senegal. Odontostomatol Trop 2001; 96: 1012

[14] Mbengue AW. Assessing the state of oral health of schoolchildren 6 to 12 years of Tivaouane department for a prevention project. Thèse: chir. Dent. Dakar 2003; 15.

[15] INSERM, UFSBD. Epidemiology of oral diseases in children 6 years and 12 years in Corsica. 2006. http://aspbd.free.fr/spip.php?article160.

[16] Schulte AG, Momeni A, Pieper K. Caries prevalence in 12year-old children from Germany. Results of the 2004 national survey. Community Dent Health 2006; 23 (4): 197-202.

[17] Pieper K, Lange J, Jablonski-Momeni A, Schulte AG. Caries prevalence in 12-year-old children from Germany: results of the 2009 national survey. Community Dent Health 2013; 30 (3): $138-42$.

[18] Milciuviene S, Matulaitiene Z, Narbutaite J, Vaitkeviciene V, Bendoraitiene E, Timofejeva I. Dental caries prevalence among 12-15-year-olds in Lithuania between 1983 and 2005. Medicina (Kaunas). 2009; 45: 68-76.

[19] Ministère de l'éducation nationale du Sénégal. "Methodological Guide of the Master: Introduction to school skills related to water, hygiene and the environment." Ten year program of education and training: Elementary Education Sub-Sector. Dakar, 2006, 71p.

[20] Fall TM. Evaluation of oral health needs in children of primary school end of the town of Diourbel. Thèse Chir. Dent. Dakar 2003; indexmedicus.afro.who.int/iah/fulltext/FALLTouty.pdf. Consulted the 22/10/15.

[21] Cisse D, Lo CMM, Faye D, Diouf M, Diongue K, Yam AA, $K a n e ~ A W$. Fluorosis and dental caries in schools in endemic fluorosis area. Rev Col Odonto-stomatol Afr Chir Maxillo-Fac 2010; $1: 5-10$.

[22] Hichour M, Persin, F, Sandeaux J, Molénat J, Gavach C. Defluoridation water by Donnan dialysis and electrodialysis. Journal of Water Science 1999; 12 (4): 671-686.

[23] Franckel A. Seeking behavior in rural health care in Senegal. The case of febrile children in Niakhar. Sociology. Université de Nanterre - Paris X, 2004. https://tel.archives-ouvertes.fr/tel00195109/document. Consulted the 23/10/15.

[24] Doumit M, Doughan B. The oral health of schoolchildren in Lebanon. Cahiers of studies and research Free / Health.2002; 12: $223-228$

[25] Okeigbemen SA. The prevalence of dental caries among 12 to 15 -year-old school children in Nigeria: report of a local survey and campaign. Oral Health Prev Dent. 2004; 2: 27-31.

[26] Diouf M, Cisse D, Faye A et al. Prevalence of necrotizing ulcerative gingivitis and associated factors in Koranic boarding schools in Senegal. Community Dent Health 2011; 20: $1-4$. 